Jurnal Teknologi Pertanian Vol. 19 No. 1 [April 2018] 33-42

Karakteristik Fries Uwi Putih (Dioscorea alata) dengan Kajian Konsentrasi Kalsium Klorida [Munawaroh dkk]

\title{
KARAKTERISTIK FRIES UWI PUTIH (DIOSCOREA ALATA) DENGAN KAJIAN KONSENTRASI KALSIUM KLORIDA DAN LAMA BLANCHING
}

\section{Characteristics of Water Yam (Dioscorea alata) Fries with Study of Calcium Chloride Concentration and Blanching Time}

\author{
Putri Syepty Sri Janatul Munawaroh ${ }^{1 *}$, Widya Dwi Rukmi Putri ${ }^{1}$, Lia Hapsari ${ }^{2}$ \\ Jurusan Teknologi Hasil Pertanian - Fakultas Teknologi Pertanian - Universitas Brawijaya \\ Jalan Veteran, Malang 65145 \\ ${ }^{2}$ UPT Balai Konservasi Tumbuhan Kebun Raya Purwodadi - Lembaga Ilmu Pengetahuan Indonesia \\ Jl. Raya Surabaya - Malang Km. 65, Pasuruan 67163 \\ *Penulis Korespondensi: email: putrisyepty@gmail.com
}

\begin{abstract}
ABSTRAK
Indonesia memiliki jenis umbi-umbian yang belum dimanfaatkan secara optimal seperti uwi putih (Dioscorea alata). Uwi putih berpotensi dikembangkan menjadi produk makanan ringan french fries. Namun permasalahannya uwi menghasilkan tekstur yang kurang renyah dan mengalami perubahan warna karena proses pencoklatan. Tujuan penelitian ini adalah mengetahui pengaruh kombinasi perlakuan konsentrasi kalsium klorida $\left(\mathrm{CaCl}_{2}\right)$ dan lama blanching terhadap sifat kimia, fisik dan organoleptik fries uwi putih (Dioscorea alata). Metode penelitian yang digunakan adalah Rancangan Acak Kelompok (RAK) yang terdiri dari 2 faktor yaitu konsentrasi kalsium klorida $\left(\mathrm{CaCl}_{2}\right)(0,1$, dan 2\%) dan lama blanching (3, 6, dan 9 menit). Data dianalisis menggunakan metode analisis ragam (ANOVA) dan dilanjutkan dengan uji lanjut BNT 5\%. Pemilihan perlakuan terbaik menggunakan metode Zeleny. Perlakuan terbaik diperoleh pada kombinasi perlakuan konsentrasi kalsium klorida $\left(\mathrm{CaCl}_{2}\right) 2 \%$ dan lama blanching 6 menit dengan kadar air $40.76 \%$; kadar pati $26.14 \%$; kadar lemak 19.62\%; kadar protein 2.78\%; kadar abu 1.09\%; tekstur $5.97 \mathrm{~N}$; kecerahan $\left(\mathrm{L}^{*}\right)$ 63.7; kemerahan $\left(a^{*}\right) 1.34$; kekuningan $\left(b^{*}\right) 15.41$; nilai organoleptik rasa 2.77; aroma 3.5; warna 3.43; tekstur 2.93; dan kenampakan 3.17
\end{abstract}

Kata kunci : Blanching, $\mathrm{CaCl}_{2}$, Fries, Tekstur, Uwi Putih, Warna

\section{ABSTRACT}

Indonesia has many kind of tubers that did not use optimally such as water yam (Dioscorea alata). Water yam can potentially developed into a product such as french fries. However, the problem of water yam has a less crispiness texture and has a colour distortion caused by browning process. The aims of this research was to determine the effect of calcium chloride concentrations $\left(\mathrm{CaCl}_{2}\right)$ and blanching time on the chemical, physical, and organoleptic characteristics of water yam (Dioscorea alata) fries. The research used a Randomized Block Design (RDB) with 2 factors that were concentration of calcium chloride $\left(\mathrm{CaCl}_{2}\right)(0,1$, and 2\%) and blanching time (3, 6, and 9 minutes). Data were analyzed using ANOVA, followed by LSD with significant level 5\%. The determination of the best treatment using multiple attribute Zeleny. The best treatment was concentration of calcium chloride $\left(\mathrm{CaCl}_{2}\right) 2 \%$ and the blanching time of 6 minutes with water content $40.76 \%$; starch $26.14 \%$; fat $19.62 \%$; protein $2.78 \%$; ash $1.09 \%$; texture $5.97 \mathrm{~N}$; lightness $\left(L^{*}\right) 63.7$; redness $\left(a^{*}\right) 1.34$; yellowness $\left(b^{*}\right) 15.41$; the value of the organoleptic taste 2.77; aroma 3.5; color 3.43; texture 2.93; and appearance of 3.17

Keywords : Blanching, $\mathrm{CaCl}_{2}$, Color, Fries, Texture, Water Yam 


\section{PENDAHULUAN}

Indonesia memiliki jenis umbi-umbian yang beragam dan tersebar di seluruh daerah, namun terdapat beberapa jenis umbi yang belum dimanfaatkan secara optimal salah satunya adalah uwi putih (Dioscorea alata), tercatat sekitar 35 varian uwi putih $(D i-$ oscorea alata) tersebar di daerah Jawa Timur (Solikin, 2009; Hapsari, 2014). Uwi putih merupakan sumber karbohidrat potensial yang dapat dikembangkan untuk memenuhi kebutuhan pangan. Komposisi kimia uwi putih meliputi $77.75 \%$ air, $16.82 \%$ pati, $2.05 \%$ protein, $0.01 \%$ lemak dan $0.83 \%$ abu (Harzau dan Estiasih, 2013). Selain berpotensi untuk kebutuhan pangan, uwi putih juga diketahui memiliki manfaat untuk kesehatan, uwi putih mengandung lendir kental yang terdiri dari glikoprotein dan polisakarida larut air. Polisakarida larut air (PLA) merupakan serat pangan larut air dan bersifat hidrokoloid yang bermanfaat untuk menurunkan kadar glukosa darah dan kadar total kolesterol. Namun selama ini uwi putih dianggap sebagai umbi minor sehingga pengolahan produk pangan berbasis uwi masih terbatas dan hanya dikonsumsi dengan cara dipotong-potong lalu direbus, dikukus atau digoreng.

Pada pengembangannya, uwi putih berpotensi dikembangkan menjadi pangan olahan seperti keripik, nugget, stik, dan french fries. French fries merupakan salah satu makanan ringan berupa potongan-potongan kentang dengan ukuran $1 \times 1 \mathrm{~cm}^{2}$, di goreng dalam minyak goreng panas, yang dapat langsung dikonsumsi dengan rasa yang gurih. Faktor kualitas utama dari french fries adalah tekstur, warna, kandungan minyak/lemak, flavour, dan kenampakan. Tekstur yang diinginkan dari french fries meliputi tekstur eksternal terkait kerenyahan dan tekstur internal terkait mealiness (rasa seperti tepung). Lapisan luar dari french fries sebaiknya tidak keras, tidak bergetah, sementara lapisan dalam bertepung (mealy) seperti kentang panggang, tidak berair atau seperti bubur, dan tidak ada pemisahan antara core dan crust. Warna yang diinginkan adalah lembut keemasan tanpa adanya warna coklat yang berlebihan atau bercak-bercak hitam dan noda. Komponen yang paling mempengaruhi warna adalah kandungan gula pereduksi. Kandungan gula pereduksi dapat dikurangi dengan perlakuan pendahuluan yaitu blanching (Lisinska dan Leszczynski, 1989).
Uwi putih juga dapat diolah menjadi pangan olahan seperti french fries yang tentunya tekstur, warna dan rasa dari fries uwi putih tidak sama dengan french fries yang terbuat dari kentang, sehingga french uwi putih dapat dijadikan alternatif di samping french fries kentang (Oluoha dan Ugochukwu, 1995; Yeh et al., 2009; Isnaini dan Khamidah, 2010). Namun, permasalahannya dalam proses pengolahan uwi menghasilkan tekstur yang kurang renyah dan mengalami perubahan warna karena proses pencoklatan. Metode untuk mengatasi masalah tekstur yang kurang renyah dapat dilakukan dengan perendaman dalam larutan kalsium klorida $\left(\mathrm{CaCl}_{2}\right)$. Penambahan bahan pengeras (firming agent) seperti $\mathrm{CaCl}_{2}$ memberi kontribusi dalam meningkatkan kekokohan jaringan, sehingga jaringan mempunyai struktur lebih kuat dan meningkatkan tekstur produk (Saldana dan Meyer, 1981; Domõ̂̂nguez et al., 2001; Isnaini dan Khamidah, 2010). Pada penelitian Anggraini (2005), konsentrasi $\mathrm{CaCl}_{2}$ yang digunakan untuk menghasilkan french fries dengan kualitas terbaik diperoleh dengan penggunaan konsentrasi $\mathrm{CaCl}_{2}$ $2 \%$. Jika penambahan $\mathrm{CaCl}_{2}$ yang digunakan lebih dari 2\%, maka menghasilkan french fries yang terasa seperti kapur.

Selain itu, metode untuk mengatasi masalah perubahan warna dapat dilakukan dengan perlakuan pendahuluan blanching. Blanching memiliki tujuan untuk menonaktifkan enzim polifenoloksidase yang menyebabkan pencoklatan pada umbi-umbian (Asgar dan Musaddad, 2006). Pada penelitian Anggraini (2005), perlakuan blanching yang digunakan untuk menghasilkan french fries perlakuan terbaik diperoleh dengan blanching selama 3 menit pada suhu $100^{\circ} \mathrm{C}$. Tujuan dari penelitian ini untuk mengetahui pengaruh konsentrasi $\mathrm{CaCl}_{2}$ dan lama blanching terhadap karakteristik fries uwi putih ( $\mathrm{Di}$ oscorea alata).

\section{BAHAN DAN METODE}

\section{Bahan}

Bahan utama pembuatan fries uwi putih yaitu uwi putih (Dioscorea alata) dipanen bulan Agustus 2016 yang diperoleh dari LIPI Purwodadi Jawa Timur. Bahan 
tambahan dalam pembuatan fries uwi putih meliputi air, $\mathrm{CaCl}_{2}$, dan minyak goreng. Bahan yang digunakan untuk analisis meliputi etanol $10 \%$, Petroleum eter, $\mathrm{HCl} 25 \%$, nelson somogyi, arseno molibdat, kertas saring halus, tablet kjedahl, $\mathrm{H}_{2} \mathrm{SO}_{4}$ pekat, HCL $0.1 \mathrm{~N}$, $\mathrm{NaOH} 45 \%$, asam borat, indikator metil red, indikator PP (Phenolphthalein), dan aquades.

\section{Alat}

Alat yang digunakan dalam pembua$\tan$ fries uwi putih meliputi kompor (Rinnai), deep fryer (Maxim Extra), lemari pendingin (Sharp), timbangan analitik (Mettler Toledo), gelas ukur $100 \mathrm{ml}$ (Pyrex), gelas beaker 250 $\mathrm{ml}$ (Pyrex), termometer (Pyrex), nampan plastik, baskom, pisau, talenan, penggaris, plastik, dan spatula.

Alat yang digunakan dalam analisis meliputi oven listrik (Memmert), perangkat titrasi (Metrohm Herisau), soxhlet (Gerhardt), shaker (Heidolph), spektrometer (Labomed), furnace (Thermolyne), refluks (Rocker), cawan petri (Iwaki), kompor listrik (Maspion), Universal Testing Machine (UTM), colour reader (Minolta CR-100), labu kjedahl, erlenmayer $250 \mathrm{ml}$ (Pyrex), pipet ukur $1 \mathrm{ml}$ (Iwaki), pipet ukur $10 \mathrm{ml}$ (Iwaki), dan pompa vakum (Rocker).

\section{Metode}

Pembuatan Fries Uwi Putih

Pengupasan uwi putih dengan pisau dan pencucian dengan air. Pemotongan uwi putih menggunakan pisau berbentuk memanjang dengan ukuran tinggi $7 \mathrm{~cm}$, dengan lebar dan panjang $7 \mathrm{~mm}$. Perendaman potongan uwi putih menggunakan larutan $\mathrm{CaCl}_{2}$ konsentrasi $0 \%$ (g/l), $1 \%$ (g/l), dan 2\% (g/l) selama 30 menit. Potongan uwi putih di blanching metode hot water blanching suhu $90{ }^{\circ} \mathrm{C}$ selama 3, 6, dan 9 menit. Uwi putih dilakukan perendaman dalam air $500 \mathrm{ml}$ selama 5 menit, lalu ditiriskan. Penggorengan I dengan deep fryer pada suhu $175^{\circ} \mathrm{C}$ selama 2 menit (hingga setengah matang), kemudian angkat, dan tiriskan. Uwi putih setengah matang dibekukan dalam freezer bersuhu $-20{ }^{\circ} \mathrm{C}$ selama 24 jam. Fries uwi putih beku dikeluarkan dari lemari pembeku (freezer), dan dilakukan penggorengan II dengan deep fryer hingga matang pada suhu $175^{\circ} \mathrm{C}$ selama 2 menit dan ditiriskan. Uwi putih yang telah menjadi fries uwi putih kemudian dianalisis kimia, fisik, dan organoleptik.

\section{Analisis Kimia}

Fries uwi putih dilakukan analisis kimia meliputi kadar air metode thermogravimetri (AOAC, 1990), kadar pati metode hidrolisa asam (AOAC, 1990), dan kadar lemak metode soxhlet (AOAC, 1990). Produk dengan hasil perlakuan terbaik dilakukan analisis proksimat berupa kadar air (AOAC, 1990), karbohidrat by different, kadar lemak (AOAC, 1990), kadar abu metode pengabuan kering (AOAC, 1990), dan kadar protein metode kjedahl (AOAC, 1990).

\section{Analisis Fisik dan Organoleptik}

Fries uwi putih dilakukan analisis fisik meliputi tekstur, dan warna $\left(\mathrm{L}, \mathrm{a}^{*}, \mathrm{~b}^{*}\right)$, serta fries uwi putih dilakukan analisis organoleptik dengan uji hedonik meliputi aroma, rasa, tekstur, warna dan kenampakan (Soekarto, 1985).

\section{Analisis Data}

Data yang diperoleh dianalisis dengan analisis ragam ANOVA dilanjutkan dengan uji BNT dengan significant level 5\%. Penentuan perlakuan terbaik dengan menggunakan metode Zeleny.

\section{HASIL DAN PEMBAHASAN}

\section{Karakteristik Bahan Baku}

Analisis proksimat yang dilakukan pada Uwi putih (Dioscorea alata) meliputi kadar air, karbohidrat by different, pati, protein, lemak, dan abu. Data hasil analisis bahan baku uwi putih dapat dilihat pada Tabel 1 .

Tabel 1 menunjukkan bahwa terdapat perbedaan hasil analisis karakteristik kimia bahan baku uwi putih dengan literatur. Perbedaan tersebut dimungkinkan karena adanya perbedaan varietas, iklim, umur panen, kondisi fisiologis tanaman, lama penyimpanan, dan jenis tanah yang berbeda.

\section{Karakteristik Kimia \\ Kadar Air}

Hasil analisis rerata kadar air fries uwi putih berkisar antara $38.06-45.48 \%$. Data hasil analisis kadar air fries uwi putih perlakuan konsentrasi $\mathrm{CaCl}_{2}$ dan lama blanching dapat dilihat pada Tabel 2. Tabel 2 menunjukkan bahwa perlakuan konsentrasi $\mathrm{CaCl}_{2}$, lama blanching dan interaksi tidak memberikan 
Tabel 1. Hasil analisis bahan baku uwi putih

\begin{tabular}{lrc}
\hline $\begin{array}{l}\text { Ko m p o s i s i } \\
(\%)\end{array}$ & Analisis* & Literatur** \\
\hline Air & $77.10 \pm 3.38$ & 77.75 \\
Karbohidrat & $20.89 \pm 3.13$ & 19.36 \\
Pati & $15.52 \pm 3.46$ & 16.82 \\
Protein & $0.86 \pm 0.01$ & 2.05 \\
Lemak & $0.97 \pm 0.23$ & 0.01 \\
Abu & $0.17 \pm 0.06$ & 0.83
\end{tabular}

Keterangan : *Setiap data merupakan rerata dari 3 ulangan. **Sumber: Harzau (2013)

Tabel 2. Rerata kadar air fries uwi putih perlakuan konsentrasi $\mathrm{CaCl}_{2}$ dan lama blanching

\begin{tabular}{ccc}
\hline $\begin{array}{c}\text { Konsentrasi } \\
\mathrm{CaCl}_{2} \text { (\%) }\end{array}$ & $\begin{array}{c}\text { Lama } \\
\text { Blanching } \\
\text { (menit) }\end{array}$ & $\begin{array}{c}\text { Rerata Nilai } \\
\text { Kadar Air }\end{array}$ \\
\hline & 3 & $40.29 \pm 8.27$ \\
0 & 6 & $39.06 \pm 5.86$ \\
& 9 & $39.67 \pm 3.49$ \\
\hline & 3 & $45.48 \pm 4.55$ \\
1 & 6 & $39.24 \pm 2.44$ \\
& 9 & $38.06 \pm 7.00$ \\
\hline & 3 & $41.48 \pm 8.68$ \\
2 & 6 & $40.76 \pm 8.28$ \\
& 9 & $40.30 \pm 5.81$
\end{tabular}

Keterangan : Data yang diperoleh merupakan rata-rata dari 3 ulangan

Tabel 3. Rerata kadar pati fries uwi putih perlakuan konsentrasi $\mathrm{CaCl}_{2}$ dan lama blanching

\begin{tabular}{ccc}
\hline $\begin{array}{c}\text { Konsentrasi } \\
\mathrm{CaCl}_{2}(\%)\end{array}$ & $\begin{array}{c}\text { Lama } \\
\text { Blanching } \\
\text { (menit) }\end{array}$ & $\begin{array}{c}\text { Rerata Nilai } \\
\text { Kadar Pati }\end{array}$ \\
\hline \multirow{2}{*}{0} & 3 & $27.50 \pm 2.64$ \\
& 6 & $28.72 \pm 1.98$ \\
& 9 & $31.95 \pm 5.05$ \\
\hline \multirow{2}{*}{1} & 3 & $24.07 \pm 5.76$ \\
& 6 & $24.38 \pm 4.60$ \\
& 9 & $29.74 \pm 3.42$ \\
\hline & 3 & $32.75 \pm 2.54$ \\
& 6 & $26.14 \pm 4.08$ \\
& 9 & $25.10 \pm 10.45$ \\
\hline
\end{tabular}

Keterangan : Data yang diperoleh merupakan rata-rata dari 3 ulangan
Tabel 4. Hasil rerata kadar lemak fries uwi putih perlakuan konsentrasi $\mathrm{CaCl}_{2}$

\begin{tabular}{ccc}
\hline $\begin{array}{c}\text { Konsentrasi } \\
\mathrm{CaCl}_{2}(\%)\end{array}$ & $\begin{array}{c}\text { Kadar Lemak } \\
(\mathbf{\%})\end{array}$ & $\begin{array}{c}\text { BNT } \\
\mathbf{5 \%}\end{array}$ \\
\hline 0 & $25.30 \pm 3.45 \mathrm{a}$ & \\
1 & $22.72 \pm 5.48 \mathrm{ab}$ & 2.19 \\
2 & $21.78 \pm 6.04 \mathrm{~b}$ & \\
\hline
\end{tabular}

Keterangan : 1. Data yang diperoleh merupakan rata-rata dari 3 ulangan; 2. Angka dengan huruf yang berbeda menunjukkan pengaruh yang berbeda nyata pada selang kepercayaan $95 \%(\alpha=0.05)$

Tabel 5. Hasil rerata kadar lemak fries uwi putih berdasarkan perlakuan lama blanching

\begin{tabular}{ccc}
\hline $\begin{array}{c}\text { Lama } \\
\text { lanching } \\
\text { (menit) }\end{array}$ & $\begin{array}{c}\text { Kadar Lemak } \\
\mathbf{( \% )}\end{array}$ & $\begin{array}{c}\text { BNT } \\
\mathbf{5 \%}\end{array}$ \\
\hline 3 & $24.93 \pm 4.20 \mathrm{a}$ & \\
6 & $22.79 \pm 8.93 \mathrm{ab}$ & 2.19 \\
9 & $22.09 \pm 3.42 \mathrm{~b}$ &
\end{tabular}

Keterangan : 1. Data yang diperoleh merupakan rata-rata dari 3 ulangan; 2. Angka dengan huruf yang berbeda menunjukkan pengaruh yang berbeda nyata pada selang kepercayaan $95 \%(\alpha=0.05)$

Tabel 6. Hasil rerata nilai tekstur fries uwi putih perlakuan konsentrasi $\mathrm{CaCl}_{2}$

\begin{tabular}{ccc}
\hline $\begin{array}{c}\text { Konsentrasi } \\
\mathrm{CaCl}_{2}(\%)\end{array}$ & Tekstur (N) & BNT 5\% \\
\hline 0 & $5.08 \pm 3.76 \mathrm{~b}$ & \\
1 & $6.71 \pm 4.80 \mathrm{a}$ & 0.98 \\
2 & $5.68 \pm 2.32 \mathrm{ab}$ & \\
\hline
\end{tabular}

Keterangan : 1. Data yang diperoleh merupakan rata-rata dari 3 ulangan; 2 . Angka dengan huruf yang berbeda menunjukkan pengaruh yang berbeda nyata pada selang kepercayaan $95 \%(\alpha=0.05)$

Tabel 7. Hasil rerata nilai tekstur fries uwi putih perlakuan lama blanching

\begin{tabular}{ccc}
\hline $\begin{array}{c}\text { Lama } \\
\text { Blanching } \\
\text { (menit) }\end{array}$ & Tekstur (N) & BNT 5\% \\
\hline 3 & $6.26 \pm 4.55 \mathrm{a}$ & \\
6 & $6.64 \pm 2.34 \mathrm{a}$ & 0.98 \\
9 & $4.57 \pm 1.39 \mathrm{~b}$ & \\
\hline
\end{tabular}

Keterangan : 1. Data yang diperoleh merupakan rata-rata dari 3 ulangan; 2. Angka dengan huruf yang berbeda menunjukkan pengaruh yang berbeda nyata pada selang kepercayaan 95\% ( $\alpha=0.05)$ 
Tabel 8. Hasil rerata nilai kecerahan $\left(L^{*}\right)$ fries uwi putih perlakuan lama blanching

\begin{tabular}{ccc}
\hline $\begin{array}{c}\text { Lama } \\
\text { Blanching } \\
\text { (menit) }\end{array}$ & Kecerahan $\left(\mathrm{L}^{*}\right)$ & $\begin{array}{c}\text { BNT } \\
\mathbf{5 \%}\end{array}$ \\
\hline 3 & $63.52 \pm 4.38 \mathrm{ab}$ & \\
6 & $61.11 \pm 7.15 \mathrm{~b}$ & 2.59 \\
9 & $64.75 \pm 2.24 \mathrm{a}$ & \\
\hline
\end{tabular}

Keterangan : 1. Data yang diperoleh merupakan rata-rata dari 3 ulangan; 2. Angka dengan huruf yang berbeda menunjukkan pengaruh yang berbeda nyata pada selang kepercayaan $95 \%(\alpha=0.05)$

Tabel 9. Hasil rerata kemerahan $\left(a^{*}\right)$ fries Uwi putih perlakuan konsentrasi $\mathrm{CaCl}_{2}$ dan lama blanching

\begin{tabular}{ccc}
\hline $\begin{array}{c}\text { Konsentrasi } \\
\mathrm{CaCl}_{2} \mathbf{( \% )}\end{array}$ & $\begin{array}{c}\text { Lama } \\
\text { Blanching } \\
\text { (menit) }\end{array}$ & $\begin{array}{c}\text { Rerata Nilai } \\
\text { Kemerahan } \\
\left(\mathbf{a}^{*}\right)\end{array}$ \\
\hline & 3 & $1.20 \pm 0.18$ \\
0 & 6 & $1.42 \pm 0.76$ \\
& 9 & $1.30 \pm 0.43$ \\
\hline & 3 & $1.20 \pm 0.49$ \\
1 & 6 & $1.17 \pm 0.12$ \\
& 9 & $1.77 \pm 0.36$ \\
\hline & 3 & $1.56 \pm 0.41$ \\
2 & 6 & $1.34 \pm 0.42$ \\
& 9 & $1.72 \pm 0.32$ \\
\hline
\end{tabular}

Keterangan : data yang diperoleh merupakan ratarata dari 3 ulangan

Tabel 10. Hasil rerata kekuningan $\left(b^{*}\right)$ fries uwi putih perlakuan konsentrasi $\mathrm{CaCl}_{2}$ dan lama blanching

\begin{tabular}{ccc}
\hline $\begin{array}{c}\text { Konsentrasi } \\
\mathbf{C a C l}_{2}(\%)\end{array}$ & $\begin{array}{c}\text { Lama } \\
\text { Blanching } \\
\text { (menit) }\end{array}$ & $\begin{array}{c}\text { Rerata Nilai } \\
\text { Kekuningan } \\
\left(\mathbf{b}^{*}\right)\end{array}$ \\
\hline \multirow{2}{*}{0} & 3 & $13.42 \pm 1.45$ \\
& 6 & $15.77 \pm 1.63$ \\
& 9 & $15.94 \pm 3.88$ \\
\hline & 3 & $15.80 \pm 1.99$ \\
& 6 & $13.90 \pm 1.86$ \\
& 9 & $15.23 \pm 4.74$ \\
\hline & 3 & $15.72 \pm 2.34$ \\
2 & 6 & $15.41 \pm 1.48$ \\
& 9 & $17.93 \pm 1.77$
\end{tabular}

Keterangan : Data yang diperoleh merupakan ratarata dari 3 ulangan
Tabel 11. Hasil rerata aroma fries uwi putih perlakuan konsentrasi $\mathrm{CaCl}_{2}$ dan lama blanching

\begin{tabular}{ccc}
\hline $\begin{array}{c}\text { Konsentrasi } \\
\mathrm{CaCl}_{2} \text { (\%) }\end{array}$ & $\begin{array}{c}\text { Lama } \\
\text { Blanching } \\
\text { (menit) }\end{array}$ & Aroma \\
\hline & 3 & $3.27 \pm 1.01 \mathrm{ab}$ \\
0 & 6 & $3.37 \pm 0.89 \mathrm{ab}$ \\
& 9 & $3.70 \pm 0.83 \mathrm{a}$ \\
\hline & 3 & $3.07 \pm 1.04 \mathrm{~b}$ \\
1 & 6 & $3.33 \pm 0.88 \mathrm{ab}$ \\
& 9 & $3.33 \pm 0.88 \mathrm{ab}$ \\
\hline & 3 & $3.10 \pm 0.99 \mathrm{ab}$ \\
2 & 6 & $3.50 \pm 0.86 \mathrm{ab}$ \\
& 9 & $3.70 \pm 0.79 \mathrm{a}$
\end{tabular}

Keterangan : 1. Data yang diperoleh merupakan rata-rata dari 3 ulangan; 2. Angka dengan huruf yang berbeda menunjukkan pengaruh yang berbeda nyata pada selang kepercayaan 95\% ( $\alpha=0.05)$

Tabel 12. Hasil rerata warna fries uwi putih perlakuan konsentrasi $\mathrm{CaCl}_{2}$ dan lama blanching

\begin{tabular}{ccc}
\hline $\begin{array}{c}\text { Konsentrasi } \\
\mathbf{C a C l}_{2} \text { (\%) }\end{array}$ & $\begin{array}{c}\text { Lama } \\
\text { Blanching } \\
\text { (menit) }\end{array}$ & Warna \\
\hline \multirow{2}{*}{0} & 3 & $3.40 \pm 1.00 \mathrm{ab}$ \\
& 6 & $3.30 \pm 0.70 \mathrm{ab}$ \\
9 & $3.53 \pm 0.78 \mathrm{a}$ \\
\hline \multirow{2}{*}{1} & 3 & $2.83 \pm 0.83 \mathrm{~b}$ \\
& 6 & $3.27 \pm 0.78 \mathrm{ab}$ \\
& 9 & $3.37 \pm 0.89 \mathrm{ab}$ \\
\hline & 3 & $3.10 \pm 0.96 \mathrm{ab}$ \\
& 6 & $3.43 \pm 0.72 \mathrm{ab}$ \\
& 9 & $3.30 \pm 0.99 \mathrm{ab}$
\end{tabular}

Keterangan : 1. Data yang diperoleh merupakan rata-rata dari 3 ulangan; 2. Angka dengan huruf yang berbeda menunjukkan pengaruh yang berbeda nyata pada selang kepercayaan $95 \%(\alpha=0.05)$ 
Tabel 13. Hasil rerata tekstur fries uwi putih perlakuan konsentrasi $\mathrm{CaCl}_{2}$ dan lama blanching

\begin{tabular}{ccc}
\hline $\begin{array}{c}\text { Konsentrasi } \\
\mathrm{CaCl}_{2} \text { (\%) }\end{array}$ & $\begin{array}{c}\text { Lama } \\
\text { Blanching } \\
\text { (menit) }\end{array}$ & $\begin{array}{c}\text { Rerata } \\
\text { Tekstur }\end{array}$ \\
\hline \multirow{2}{*}{0} & 3 & $3.50 \pm 0.81$ \\
& 6 & $3.47 \pm 0.91$ \\
& 9 & $3.40 \pm 0.86$ \\
\hline & 3 & $3.40 \pm 0.83$ \\
& 6 & $3.27 \pm 1.10$ \\
2 & 9 & $3.17 \pm 1.01$ \\
\hline & 3 & $2.93 \pm 0.91$ \\
& 6 & $2.90 \pm 0.94$ \\
& 9 & $2.83 \pm 0.99$
\end{tabular}

Keterangan : Data yang diperoleh merupakan rata-rata dari 3 ulangan

Tabel 14. Hasil rerata rasa fries uwi putih perlakuan konsentrasi $\mathrm{CaCl}_{2}$ dan lama blanching

\begin{tabular}{ccc}
\hline $\begin{array}{c}\text { Konsentrasi } \\
\mathrm{CaCl}_{2}(\%)\end{array}$ & $\begin{array}{c}\text { Lama } \\
\text { Blanching } \\
\text { (menit) }\end{array}$ & Rerata Rasa \\
\hline & 3 & $3.40 \pm 1.00$ \\
0 & 6 & $3.40 \pm 085$ \\
& 9 & $3.40 \pm 0.81$ \\
\hline & 3 & $3.37 \pm 0.83$ \\
1 & 6 & $3.33 \pm 1.00$ \\
& 9 & $3.10 \pm 0.92$ \\
\hline & 3 & $2.93 \pm 1.06$ \\
2 & 6 & $2.90 \pm 0.90$ \\
& 9 & $2.77 \pm 0.76$ \\
\hline
\end{tabular}

Keterangan : Data yang diperoleh merupakan rata-rata dari 3 ulangan
Tabel 15. Hasil rerata kenampakan fries uwi putih perlakuan konsentrasi $\mathrm{CaCl}_{2}$ dan lama blanching

\begin{tabular}{ccc}
\hline $\begin{array}{c}\text { Konsentrasi } \\
\mathrm{CaCl}_{2}(\%)\end{array}$ & $\begin{array}{c}\text { Lama } \\
\text { Blanching } \\
\text { (menit) }\end{array}$ & $\begin{array}{c}\text { Rerata } \\
\text { Kenampakan }\end{array}$ \\
\hline & 3 & $3.60 \pm 0.74$ \\
0 & 6 & $3.53 \pm 0.73$ \\
& 9 & $3.50 \pm 0.72$ \\
\hline & 3 & $3.50 \pm 0.68$ \\
1 & 6 & $3.27 \pm 0.94$ \\
& 9 & $3.20 \pm 0.94$ \\
\hline & 3 & $3.17 \pm 0.91$ \\
2 & 6 & $3.17 \pm 0.70$ \\
& 9 & $3.13 \pm 0.96$
\end{tabular}

Keterangan : Data yang diperoleh merupakan rata-rata dari 3 ulangan

Tabel 16. Perlakuan terbaik fries uwi putih

\begin{tabular}{lc}
\hline Parameter & Fries Uwi Putih* \\
\hline Kadar air (\%) & 40.76 \\
Kadar Karbohidrat (\%) & 35.75 \\
Kadar Pati (\%) & 26.14 \\
Kadar lemak (\%) & 19.62 \\
Kadar Protein (\%) & 2.78 \\
Kadar Abu (\%) & 1.09 \\
Aroma & 3.50 \\
Warna & 3.43 \\
Tekstur & 2.93 \\
Rasa & 2.77 \\
Kenampakan & 3.17
\end{tabular}

Keterangan : ${ }^{*}$ Setiap data merupakan rata-rata dari 3 ulangan 
pengaruh nyata $(\alpha=0.05)$ terhadap nilai kadar air. Hal ini diduga rendahnya konsentrasi $\mathrm{CaCl}_{2}$ tidak berperan signifikan dalam kereaktifan air. Sari (2010) menyatakan bahwa $\mathrm{CaCl}_{2}$ dapat memperkokoh jaringan dinding sel bahan, dengan semakin meningkatnya konsentrasi $\mathrm{CaCl}_{2}$ maka ion $\mathrm{Ca}^{2+}$ yang berikatan dengan gugus karbonil akan semakin meningkat. Apabila jumlah ikatan menyilang yang terbentuk banyak, struktur jaringan akan semakin kuat dan tekstur menjadi keras sehingga dapat mempertahankan keberadaan air dalam bahan. Ayu dan Yuwono (2014) juga menyatakan bahwa perlakuan lama blanching dapat mengakibatkan sifat permeable dinding sel yang meningkat. Panas yang kontak dengan bahan mengakibatkan perubahan karakteristik struktur pada jaringan sel. Tetapi pada penelitian ini lama blanching yang digunakan tidak berpengaruh pada komponen struktur jaringan sel sehingga kadar air dari produk tidak berbeda nyata.

\section{Kadar Pati}

Hasil analisis rerata kadar pati fries uwi putih berkisar antara $24.07-32.75 \%$. Data hasil analisis kadar pati fries uwi putih perlakuan konsentrasi $\mathrm{CaCl}_{2}$ dan lama blanching dapat dilihat pada Tabel 3. Tabel 3 menunjukkan bahwa perlakuan konsentrasi $\mathrm{CaCl}_{2^{\prime}}$ lama blanching dan interaksi tidak memberikan pengaruh nyata $(\alpha=0.05)$ terhadap nilai kadar pati. Hal ini diduga karena $\mathrm{CaCl}_{2}$ dalam bahan pangan memiliki kecenderungan untuk berikatan dengan jaringan sel pada bahan, sehingga tidak berpengaruh besar terhadap hilangnya kadar pati. Selain itu, diduga proses blanching yang dilakukan tidak berpotensi untuk menimbulkan kerusakan pada pati yang dapat disebabkan karena bahan yang digunakan berupa uwi putih mengandung lendir sehingga menghalangi pati untuk dapat terlarut dalam air (Yeh et al., 2009).

\section{Kadar Lemak}

Hasil analisis rerata kadar lemak fries uwi putih berkisar antara 21.78-25.30\%. Hasil rerata kadar lemak fries uwi putih perlakuan konsentrasi $\mathrm{CaCl}_{2}$ dan lama blanching dapat dilihat pada Tabel 4 dan Tabel 5. Tabel 4 menunjukkan bahwa perlakuan konsentrasi $\mathrm{CaCl}_{2}$ memberikan pengaruh nyata $(\alpha=0.05)$ terhadap nilai kadar lemak. Kadar lemak fries uwi putih dengan pemberian kon- sentrasi $\mathrm{CaCl}_{2} 0 \%$ menghasilkan nilai yang paling tinggi, serta dengan bertambahnya konsentrasi $\mathrm{CaCl}_{2}$ dihasilkan kadar lemak yang semakin menurun. Hal ini karena semakin tinggi konsentrasi $\mathrm{CaCl}_{2}$ dapat memperkuat ikatan dalam sel-sel jaringan pada bahan, sehingga mengurangi pemisahan sel ketika proses penggorengan. $\mathrm{CaCl}_{2}$ membentuk ikatan silang dalam jaringan bahan, yang menyebabkan pori-pori bahan rapat, sehingga menyulitkan keluarnya air dalam bahan. Semakin tinggi konsentrasi $\mathrm{CaCl}_{2}$ maka ikatan silang yang terbentuk semakin banyak sehingga struktur menjadi lebih rapat. Tabel 5 menunjukkan bahwa perlakuan lama blanching memberikan pengaruh nyata $(\alpha=0.05)$ terhadap nilai kadar lemak. Wei Xiao et al. (2017) menyatakan bahwa proses blanching yang lebih lama menyebabkan sifat permeabilitas dalam jaringan membesar, yang menyebabkan komponen dalam jaringan seperti pati mengalami pembengkakan karena terjadinya penyerapan air yang terperangkap pada susunan molekul-molekul pati sehingga menyerap air lebih tinggi. Adanya proses pendinginan setelah dilakukan proses blanching dapat menyebabkan terjadinya retrogradasi pati, dimana struktur pati akan semakin rapat karena penurunan suhu. Hal ini yang mengakibatkan sifat permeabilitas pada jaringan lebih rendah sehingga ketika dilakukan proses penggorengan minyak dapat ditiriskan dengan baik, sehingga menghasilkan kadar lemak yang cenderung mengalami penurunan dengan semakin meningkatnya lama blanching.

\section{Karakteristik Fisik Tekstur}

Hasil analisis rerata tekstur fries uwi putih berkisar antara 4.57-6.71 N. Data hasil analisis tekstur fries uwi putih perlakuan konsentrasi $\mathrm{CaCl}_{2}$ dan lama blanching dapat dilihat pada Tabel 6 dan Tabel 7. Tabel 6 menunjukkan bahwa perlakuan konsentrasi $\mathrm{CaCl}_{2}$ memberikan pengaruh nyata $(\alpha=0.05)$ terhadap tekstur. Menurut Isnaini dan Khamidah (2010), penambahan bahan pengeras (firming agent) seperti $\mathrm{CaCl}_{2}$ memberi kontribusi dalam meningkatkan kekokohan jaringan sel, semakin tinggi konsentrasi $\mathrm{CaCl}_{2}$ maka tekstur fries yang dihasilkan semakin keras, karena dengan adanya $\mathrm{CaCl}_{2}$ dalam larutan maka ion $\mathrm{Ca}^{2+}$ akan memperkuat dinding sel. Pada saat pengolahan lebih lanjut, ketegaran dinding sel dapat dipertahankan dan setelah 
mengalami proses penggorengan produk akan lebih renyah. Tabel 7 menunjukkan bahwa perlakuan lama blanching memberikan pengaruh nyata $(\alpha=0.05)$ terhadap nilai tekstur. Ayu dan Yuwono (2014) menyatakan bahwa blanching yang terlalu lama akan menyebabkan tekstur menjadi terlalu lunak karena blanching dapat mengakibatkan sifat permeable dinding sel yang meningkat. Panas yang kontak dengan bahan dapat mengakibatkan pengembangan struktur granula pati, granula pati tersebut akan menyerap air sehingga uap air yang terserap dalam bahan akan semakin banyak, sehingga tekstur yang dihasilkan lunak. Menurut Kita et al. (2005), proses blanching, pra-pengeringan, dan penggorengan dalam proses pengolahan french fries dapat menyebabkan perubahan struktur jaringan pada french fries.

\section{Nilai Kecerahan $\left(\mathrm{L}^{*}\right)$}

Hasil analisis rerata kecerahan $\left(\mathrm{L}^{*}\right)$ fries uwi putih berkisar antara 61.11-64.75. Data hasil analisis kecerahan $\left(\mathrm{L}^{*}\right)$ fries uwi putih perlakuan lama blanching dapat dilihat pada Tabel 8 . Tabel 8 menunjukkan bahwa perlakuan lama blanching memberikan pengaruh nyata $(\alpha=0.05)$ terhadap kecerahan $\left(\mathrm{L}^{*}\right)$. Namun konsentrasi $\mathrm{CaCl}_{2}$ dan interaksi tidak memberikan pengaruh yang nyata $(\alpha=0.05)$ terhadap kecerahan $\left(\mathrm{L}^{*}\right)$. Hal ini diduga dengan semakin lama blanching dengan suhu diatas $70{ }^{\circ} \mathrm{C}$ dapat menonaktifkan enzim polifenoloksidase sehingga mencegah perubahan warna (Siddiq et al., 1992). Menurut Estiasih dan Ahmadi (2009), dengan adanya perlakuan blanching maka enzim polifenoloksidase dalam bahan dapat dinonaktifkan sehingga perubahan warna akibat reaksi pencoklatan enzimatis dapat diminimalkan. Semakin lama blanching yang berlangsung maka semakin lama pula panas berkontak dengan bahan. Hal tersebut mengakibatkan semakin efektif pula air dan panas dalam menginaktivasi enzim polifenolase, sehingga semakin lama blanching dapat meningkatkan nilai kecerahan dari fries uwi putih. Menurut Sun et al. (2010), polifenol oksidase mengkatalis oksidasi polifenol menjadi a-kuinon dengan adanya oksigen dan a-kuinon berpolimerisasi yang menyebabkan timbulnya pencoklatan atau timbulnya pigmen yang tidak diinginkan.

\section{Nilai Kemerahan ( $\left.a^{*}\right)$}

Hasil analisis rerata kemerahan $\left(\mathrm{a}^{*}\right)$ fries uwi putih berkisar antara 1.17-1.77. Data hasil analisis kemerahan $\left(\mathrm{a}^{*}\right)$ fries uwi putih perlakuan konsentrasi $\mathrm{CaCl}_{2}$ dan lama blanching dapat dilihat pada Tabel 9. Tabel 9 menunjukkan bahwa perlakuan konsentrasi $\mathrm{CaCl}_{2}$, lama blanching dan interaksi tidak memberikan pengaruh nyata $(\alpha=0.05)$ terhadap kemerahan (a*). $\mathrm{CaCl}_{2}$ dapat digunakan untuk mengurangi reaksi pencoklatan pada bahan, reaksi maillard yang terjadi melibatkan suhu tinggi, dimana terjadinya reaksi antara asam amino dengan gula pereduksi yang dapat menyebabkan pencoklatan pada bahan. Pada proses penggorengan, reaksi maillard dapat menjadi penentu rasa, warna, aroma dan tekstur dari bahan yang digoreng (Codex Alimentarius, 2017).

\section{Nilai Kekuningan (b*)}

Hasil analisis rerata kekuningan $\left(b^{*}\right)$ fries uwi putih berkisar antara 13.42-17.93. Data hasil analisis kekuningan $\left(b^{*}\right)$ fries uwi putih perlakuan konsentrasi $\mathrm{CaCl}_{2}$ dan lama blanching dapat dilihat pada Tabel 10. Tabel 10 menunjukkan bahwa perlakuan konsentrasi $\mathrm{CaCl}_{2}$, lama blanching dan interaksi tidak memberikan pengaruh nyata $(\alpha=0.05)$ terhadap kekuningan $\left(b^{*}\right)$. Perubahan warna pada french fries dapat disebabkan karena adanya reaksi pencoklatan yang terjadi pada bahan. Pada proses penggorengan, reaksi maillard dapat menjadi penentu rasa, warna, aroma dan tekstur dari bahan yang digoreng.

\section{Karakteristik Organoleptik Aroma}

Hasil analisis rerata aroma fries uwi putih berkisar antara 3.07-3.70. Data hasil analisis aroma fries uwi putih perlakuan konsentrasi $\mathrm{CaCl}_{2}$ dan lama blanching dapat dilihat pada Tabel 11.

Tabel 11 menunjukkan bahwa perlakuan konsentrasi $\mathrm{CaCl}_{2}$ dan lama blanching memberikan pengaruh nyata $(\alpha=0.05)$ terhadap aroma. Hal ini diduga aroma yang tinggi berasal dari aroma minyak ketika proses penggorengan, karena dalam bahan terdapat kandungan gugus amino dan gula reduksi yang dapat menyebabkan reaksi maillard sehingga menghasilkan senyawa volatil khas produk goreng (Sari, 2010). 


\section{Warna}

Hasil analisis rerata warna fries uwi putih berkisar antara 2.83-3.53. Data hasil analisis warna fries uwi putih perlakuan konsentrasi $\mathrm{CaCl}_{2}$ dan lama blanching dapat dilihat pada Tabel 12. Tabel 12 menunjukkan bahwa perlakuan konsentrasi $\mathrm{CaCl}_{2}$ dan lama blanching memberikan pengaruh nyata $(\alpha=0.05)$ terhadap warna. Hal ini diduga dengan semakin lama blanching dapat mencegah reaksi pencoklatan enzimatis. Menurut Siddiq et al. (1992) menyatakan bahwa perlakuan blanching diatas $70^{\circ} \mathrm{C}$ dapat menginaktifkan enzim polifenoloksidase pada umbi-umbian sehingga perubahan warna dapat dicegah. Selain itu, adanya proses penggorengan dalam pengolahan fries uwi putih juga berpengaruh dalam memacu terjadinya reaksi maillard. Warna suatu produk merupakan daya tarik utama sebelum komponen mengenal dan menyukai sifat-sifat lainnya. Warna fries uwi putih disebabkan adanya proses pencoklatan (browning) yang terjadi pada bahan.

\section{Tekstur}

Hasil analisis rerata tekstur fries uwi putih berkisar antara 2.83-3.50. Data hasil analisis tekstur fries uwi putih perlakuan konsentrasi $\mathrm{CaCl}_{2}$ dan lama blanching dapat dilihat pada Tabel 13. Tabel 13 menunjukkan bahwa perlakuan konsentrasi $\mathrm{CaCl}_{2}$ dan lama blanching tidak memberikan pengaruh nyata $(\alpha=0.05)$ terhadap tekstur. Hal ini diduga karena tingkat penilaian panelis terhadap setiap perlakuan memiliki tekstur yang tidak terlalu berbeda jauh. Tingkat kesukaan tekstur juga dapat disebabkan oleh tingkat selera tiap orang yang berbeda-beda. Menurut Kita et al. (2005), tekstur dalam french fries memiliki dua arti yaitu tekstur bagian luar (kerenyahan) dan bagian dalam (sifat masir), tetapi dalam hal ini lebih diutamakan pada kerenyahan.

\section{Rasa}

Hasil analisis rerata rasa fries uwi putih berkisar antara 2.77-3.40. Data hasil analisis rasa fries uwi putih perlakuan konsentrasi $\mathrm{CaCl}_{2}$ dan lama blanching dapat dilihat pada Tabel 14. Tabel 14 menunjukkan bahwa perlakuan konsentrasi $\mathrm{CaCl}_{2}$ dan lama blanching tidak memberikan pengaruh nyata $(\alpha=0.05)$ terhadap rasa. Hal ini diduga karena terjadinya reaksi maillard ketika penggorengan yang menghasilkan senyawa volatil khas produk goreng sehingga secara keseluruhan rasa yang dihasilkan antara satu perlakuan dengan yang lain tidak terlalu jauh berbeda (Sari, 2010).

\section{Kenampakan}

Hasil analisis rerata kenampakan fries uwi putih berkisar antara 3.13-3.60. Data hasil analisis kenampakan fries uwi putih perlakuan konsentrasi $\mathrm{CaCl}_{2}$ dan lama blanching dapat dilihat pada Tabel 15. Tabel 15 menunjukkan bahwa perlakuan konsentrasi $\mathrm{CaCl}_{2}$ dan lama blanching tidak memberikan pengaruh nyata $(\alpha=0.05)$ terhadap kenampakan. Kesukaan panelis terhadap kenampakan fries uwi putih menunjukkan kesukaan yang hampir sama terhadap semua kombinasi perlakuan. Hal ini juga dipengaruhi oleh rasa fries uwi putih yang menurut panelis tidak memiliki perbedaan yang nyata antara masing-masing kombinasi perlakuan, sehingga kesukaan panelis pada masing-masing kombinasi tersebut hampir sama tidak berbeda terlalu jauh.

\section{Perlakuan Terbaik}

Penentuan perlakuan terbaik terhadap parameter kimia, fisik, dan organoleptik fries uwi putih dilakukan berdasarkan analisis multiple attribute (Zeleny, 1992). Pada penelitian ini diperoleh perlakuan terbaik yaitu pada perlakuan konsentrasi $\mathrm{CaCl}_{2} 2 \%$ dan lama blanching 6 menit. Adapun perlakuan terbaik dari fries uwi putih disajikan pada tabel 16. Pada Tabel 16 menunjukkan bahwa uwi putih dapat dikembangkan menjadi olahan pangan, sebagai bahan baku alternatif dalam pembuatan french fries.

\section{SIMPULAN}

Perlakuan pengaruh konsentrasi $\mathrm{CaCl}_{2}$ memberikan perbedaan yang nyata $(\alpha=0.05)$ terhadap kadar lemak, tekstur, aroma, dan warna. Perlakuan lama blanching memberikan perbedaan yang nyata $(\alpha=0.05)$ terhadap kadar lemak, tekstur, kecerahan $\left(\mathrm{L}^{*}\right)$, aroma, dan warna. Namun, interaksi antar perlakuan konsentrasi $\mathrm{CaCl}_{2}$ dan lama blanching tidak memberikan pengaruh nyata $(\alpha=0.05)$ terhadap keseluruhan karakteristik kimia, fisik, dan organoleptik. Perlakuan terbaik diperoleh pada kombinasi perlakuan konsentrasi $\mathrm{CaCl}_{2}$ 2\% dan lama blanching 6 menit dengan kadar air $40.76 \%$, kadar pati $26.14 \%$, 
kadar lemak 19.62\%, kadar protein 2.78\%, kadar abu $1.09 \%$, tekstur $5.97 \mathrm{~N}$, kecerahan $\left(\mathrm{L}^{*}\right)$ 63.7, kemerahan $\left(\mathrm{a}^{*}\right)$ 1.33, kekuningan $\left(b^{*}\right) 15.41$, rasa 2.77 , aroma 3.50 , warna 3.43 , tekstur 2.93, dan kenampakan 3.17.

\section{DAFTAR PUSTAKA}

Anggraini, K. 2005. Pengaruh Metode Blanching dan Pencelupan dalam Lemak Jenuh terhadap Kualitas French fries Kentang Varietas Hertha dan Granola. Skripsi. Universitas Jenderal Soedirman, Purwokerto

AOAC. 1990. Official Methods of Analysis. Association of Official Analysis Chemistry, Washington

Asgar, A, Musaddad, D. 2006. Optimalisasi cara, suhu dan lama blanching sebelum pengeringan pada kubis. Jurnal Hortikultura. 16(4):349-355

Ayu, C, D, Yuwono, S, S. 2014. Pengaruh suhu blanching dan lama perendaman terhadap sifat kimia tepung kimpul (Xanthosoma sagittifolium). Jurnal Pangan dan Agroindustri. 2(2):110-120

Codex Alimentarius. 2017. Standard for processed cereal-based foods for infants and young children. Dilihat 20 November 2017. <http://www.fao.org/faowho-codexalimentarius/sh-proxy/en/ ?lnk=1\&url=https \% 253A \% 252F\% 252F workspace.fao.org $\% 252$ Fsites $\% 252 \mathrm{Fcod}$ ex $\% 252$ FStandards $\% 252$ FCODEX $\% 2 B S$ TAN\%2B74-1981\%252FCXS_074e.pdf>

DomõÂnguez, R, Quintero-Ramos, A, Bourne, M, Barnard, J, TalamaÂs-Abbud, R, JimeÂnez-Castro, J, AnzalduÂA a-Morales, A. 2001. International Journal of Food Science and Technology. 36:523-527

Estiasih, T, Ahmadi, kgs. 2009. Teknologi Pengolahan Pangan. Bumi Aksara, Jakarta

Hapsari, R, T. 2014. Prospek uwi sebagai pangan fungsional dan bahan diversifikasi pangan. Buletin Palawija. 27:26-38

Harzau, H, Estiasih, T. 2013. Karakteristik cookies umbi inferior uwi putih (kajian proporsi tepung uwi: pati jagung dan penambahan margarin). Jurnal Pangan dan Agroindustri. 1(1):138-147

Isnaini, L., Khamidah L. 2010. Kajian lama blanching dan konsentrasi $\mathrm{CaCl}_{2}$ terhadap sifat fisik pembuatan french fries ubi jalar (Ipomoea Batatas L.). Dilihat
20 November 2017. < https:/ / anzdoc. com/kajian-lama-blanching-dan-konsentrasi-cacl-2-terhadap-sifat-.html>

Kita, A, Lisińska, G, Powolny, M. 2005. The influence of frying medium degradation on fat uptake and texture of french fries. Journal of The Science of Food and Agriculture. 85(7):1113-1118

Lisinska, G, Leszeczynski, W. 1989. Potato Science and Technology. Elsevier, New York

Oluoha, U, Ugochukwu, E, N. 1995. Comparison of structure and kinetic mechanism of phosphorylase forms isolated from water yam (Dioscorea alata) and white yam (Dioscorea rotundata) tubers. Phytochemistry. 40(3):677-684

Saldana, G, Meyer, R. 1981. Effects of added calcium on texture and quality of canned jalapeno peppers. Journal of Food Science. 46(5):1518-1520

Sari, TK. 2010. Pengaruh metode blanching dan perendaman dalam kalsium klorida $\left(\mathrm{CaCl}_{2}\right)$ untuk meningkatkan kualitas french fries dari kentang varietas tenggo dan crespo. Skripsi. Universitas Jenderal Soedirman. Purwokerto

Siddiq, M, Sinha, N, K, Cash, J, N. 1992. Characterization of polyphenoloxidase from stanley plums. Journal of Food Science. 57(5):1177-1179

Soekarto, ST. 1985. Penilaian Organoleptik untuk Industri Pangan dan Pertanian. Bhratara Karya Aksara. Jakarta

Solikin. 2009. Dioscorea sebagai bahan pangan. Prosiding Seminar Nasional Peranan Ilmu dan Teknologi Pertanian dalam Mewujudkan Ketahanan Pangan, Universitas Udayana, Bali, pp. 32-38

Sun, J, Y, You, E, G, Long, X, Wang, J. 2010. Biochemical properties and potential endogenous substrates of polyphenoloxidase from chufa (Eleocharis tuberosa) corms. Food Chemistry. 118(3):799-803

Wei Xiao, H, Pan, Z, Deng, L, D, El-Mashad, H, M, Yang, X, H, Mujumdar, A, S, Gao, Z, J, Zhang, Q. 2017. Recent developments and trends in thermal blanching - a comprehensive review. Information Processing in Agriculture. 4(2):101-127

Yeh, A, I, Chan, T, Y, Chuang, G, C. 2009. Effect of water content and mucilage on physico-chemical characteristics of yam (Discorea alata purpurea) starch. Journal of Food Engineering. 95:106-114

Zeleny, M. 1992. Multiple Criteria Decision Making. McGraw-Hill Co, New York 